\title{
POLLEN FORMATION IN PENTAPLOID AND NEAR-PENTAPLOID WHEAT HYBRIDS
}

\author{
J. W. MORRISON \\ John Innes Horticultural Institution, Hertford \\ (now at Cereal Division, C.E.F. Ottowa)
}

Received r.i.53

\section{INTRODUCTION}

INTERSPECIFIC wheat crosses have been investigated cytologically at various times throughout the last few years. Interest has fluctuated with the importance of the hybridising work and the success with which disease resistance has been introduced from the tetraploid species, $4^{x}=28$, into the hexaploid wheats, $6 x=42$. The present study was stimulated by a new technique for examining the chromosomes at the mitoses in the pollen grains. Meiotic studies were also made because of the doubt cast on the validity of some of the earlier reports (Love, I94I). At the same time, material on hand made it possible to compare the behaviour in near-pentaploid plants and in pentaploid plants.

\section{METHODS AND MATERIALS}

All P.M.C's. were examined from squash preparations stained in aceto-carmine. Root-tips were pre-treated with monobromonaphthalene, fixed in $2 \mathrm{BD}$ and then prepared as Feulgen squashes. Mitoses in pollen grains were examined using the method outlined previously (Morrison, 1953).

The following $F_{1}$ material was examined in detail :-

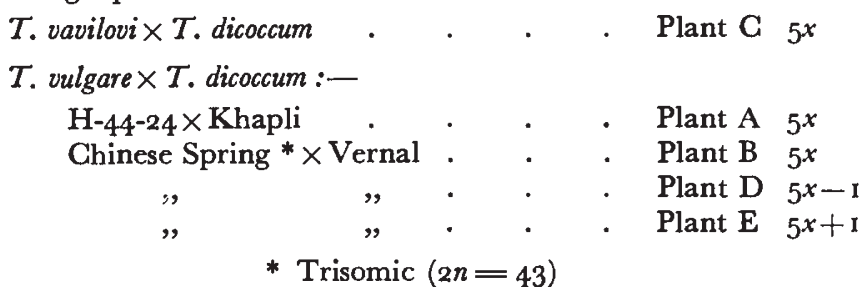

\section{METAPHASE I}

In all pentaploids and near-pentaploids no more than 14 bivalents per nucleus were formed (table I). Pairing varied among the P.M.C's., with from 9 to 14 bivalents per cell within the same anther (figs. $3 \mathrm{~A}$ and $\mathbf{B})$. This variation contradicts previous reports that the pentaploid regularly forms $14^{11} 7^{1}$ at meiosis (Kihara, I938; Aase, 1935, and Thompson, I934, among others).

If the missing chromosome in plant $\mathrm{D}$ has a homologue in the 
set of $T$. dicoccum, then the maximum pairing expected will be only I 3 bivalents (table I). The seven from $T$. vulgare plus the unmated dicoccum-chromosome will give 8 univalents. The extra chromosome in the parental trisomic was therefore one of the first 14 chromosomes (A and B genomes of Kihara). Trivalents are therefore expected in plant $\mathrm{E}$ and in the majority of P.M.C's. $-\mathrm{I}^{111} 13^{11} 7^{1}$. Chain trivalents were formed from two chiasmata ; the rod-ring type (Mather, 1935) from three.

TABLE I

Comparison of the pairing behaviour in pentaploid and near-pentaploid wheat hybrids. Univalents are not indicated

\begin{tabular}{|c|c|c|c|c|c|c|c|}
\hline \multicolumn{4}{|c|}{$5^{x}$} & \multicolumn{2}{|c|}{$5^{x-1}$} & \multicolumn{2}{|c|}{$5^{x+1}$} \\
\hline MI arrangement & $\begin{array}{l}\text { Plant A } \\
\text { (in } \\
\text { per cent.) }\end{array}$ & $\begin{array}{c}\text { Plant B } \\
\text { (in } \\
\text { per cent.) }\end{array}$ & $\begin{array}{c}\text { Plant C } \\
\text { (in } \\
\text { per cent.) }\end{array}$ & $\begin{array}{c}\text { MI } \\
\text { arrange- } \\
\text { ment }\end{array}$ & $\begin{array}{c}\text { Plant D } \\
\text { (in } \\
\text { per cent.) }\end{array}$ & $\begin{array}{c}\text { MI } \\
\text { pairing }\end{array}$ & $\begin{array}{c}\text { Plant E } \\
\text { (in } \\
\text { per cent.) }\end{array}$ \\
\hline $\begin{array}{r}14^{11} \\
\mathrm{I} 3^{11} \\
\mathrm{I} 2^{11} \\
\mathrm{I} 1^{11} \\
\mathrm{I} 0^{11} \\
9^{11}\end{array}$ & $\begin{array}{r}31 \cdot 1 \\
36 \cdot 7 \\
17 \cdot 8 \\
11 \cdot 1 \\
2 \cdot 2 \\
1 \cdot 1\end{array}$ & $\begin{array}{c}67 \cdot 0 \\
28 \cdot 0 \\
4 \cdot 0 \\
1 \cdot 0 \\
\ldots \\
\ldots\end{array}$ & $\begin{array}{c}78 \cdot 0 \\
18 \cdot 0 \\
4 \cdot 0 \\
\ldots \\
\ldots \\
\cdots\end{array}$ & $\begin{array}{r}13^{11} \\
12^{11} \\
11^{11} \\
10^{11} \\
9^{11} \\
7^{11}\end{array}$ & $\begin{array}{r}44 \cdot 0 \\
39 \cdot 0 \\
11 \cdot 0 \\
3 \cdot 0 \\
2 \cdot 0 \\
1 \cdot 0\end{array}$ & $\begin{array}{l}\mathrm{I} 4^{11} \\
\mathrm{I} 3^{11} \mathrm{I}^{111} \\
\mathrm{I} 3^{11} \\
\mathrm{I} 2^{111} \mathrm{I}^{111} \\
\mathrm{I} 2^{11} \\
\quad \ldots\end{array}$ & $\begin{array}{c}20 \cdot 0 \\
46 \cdot 0 \\
10 \cdot 0 \\
14 \cdot 0 \\
10 \cdot 0 \\
\ldots\end{array}$ \\
\hline No. of P.M.C's. examined & 90 & I00 & 50 & & I 00 & & $5^{0}$ \\
\hline $\begin{array}{l}\text { Mean no. of bivalents } \\
\text { per P.M.C. }\end{array}$ & $12 \cdot 8$ & $13 \cdot 6$ & $13 \cdot 7$ & & $12 \cdot 1$ & & $13 \cdot 6 *$ \\
\hline
\end{tabular}

* Trivalents calculated as bivalents.

At diplotene-diakinesis, in some cells it was difficult to distinguish between bivalents and univalents because of grouping around the nucleolus. However, in all cells with well-spread chromosomes there were I 4 pairs, associated no doubt sometimes only by coiling. Horton (1936) also observed I4 pairs in pre-metaphase stages. The variation in pairing at MI is characteristic of all hybrids and is a result of the variability in chiasma formation following interrupted pachytene pairing. Some of the reduction in chiasmata may also be attributed to environment (Mather, I 935, and Li et al., 1945).

Love (I94I) found similar variation in the pairing behaviour in pentaploids. In one hybrid of $T$. vulgare $\times T$. durum the pairing arrangement $14^{11} 7^{1}$ was only present in 5 per cent. of the cells. Love also found trivalents and higher associations. Except for two doubtful trivalents in plant B, I found no higher associations in the 35 -chromosome plants. 


\section{ANAPHASE I AND TELOPHASE |}

At AI and TI my results again disagree with previous results. Some of the univalents split equationally in the first division and are distributed at random in the second. But all of them do not. In plant $\mathrm{C}$ in a squash of three anthers, there were 6o cells at AI where the distribution at the poles could be counted (table 2). In $\mathrm{B}$, the

TABLE 2

Frequency of chromosome distribution to the poles and the number of laggards remaining between them at $A I, T I$ and $T I I$

\begin{tabular}{|c|c|c|c|c|c|}
\hline \multirow{2}{*}{$\begin{array}{l}\text { No. of laggards } \\
\text { lying between } \\
\text { the poles }\end{array}$} & \multicolumn{3}{|c|}{ AI } & \multirow{2}{*}{$\frac{\text { TI }}{\underbrace{}_{\begin{array}{c}\text { Per cent. of } \\
\text { cells with } \\
\text { laggards }\end{array}}}$} & \multirow{2}{*}{$\begin{array}{c}\text { TII } \\
\begin{array}{c}\text { Per cent. of } \\
\text { cells with } \\
\text { laggards }\end{array}\end{array}$} \\
\hline & $\begin{array}{l}\text { Distribution of } \\
\text { chromosomes to } \\
\text { the poles }\end{array}$ & $\begin{array}{l}\text { No. of } \\
\text { cells with } \\
\text { laggards }\end{array}$ & $\begin{array}{l}\text { Per cent. of } \\
\text { cells with } \\
\text { laggards }\end{array}$ & & \\
\hline o & $17: 18$ & I & $1 \cdot 7$ & $\ldots$ & \\
\hline I & $\begin{array}{l}17: 17 \\
16: 18\end{array}$ & $\begin{array}{l}\mathrm{I} \\
\mathrm{I}\end{array}$ & $3 \cdot 3$ & $2 \cdot 5$ & $3 \cdot 8$ \\
\hline $\begin{array}{l}2 \\
3\end{array}$ & $16: 16$ & 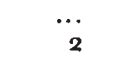 & $\begin{array}{l}\ldots \\
\text { 10.0 }\end{array}$ & $\begin{array}{l}10 \cdot 0 \\
15.0\end{array}$ & $\begin{array}{r}8.8 \\
19.5\end{array}$ \\
\hline & & $\begin{array}{l}3 \\
\mathrm{I}\end{array}$ & & & \\
\hline 4 & $\begin{array}{l}15: 16 \\
14: 17\end{array}$ & 7 & $16 \cdot 7$ & $12 \cdot 5$ & $19 \cdot 5$ \\
\hline 5 & $\begin{array}{l}14: 17 \\
15: 15\end{array}$ & $\begin{array}{l}\breve{8} \\
3\end{array}$ & $18 \cdot 3$ & $25^{\circ} 0$ & $23 \cdot 9$ \\
\hline 6 & $14: 15$ & 17 & $28 \cdot 3$ & 175 & 15.7 \\
\hline 78 & I $4:$ I 4 & II & $18 \cdot 3$ & $\begin{array}{r}10 \cdot 0 \\
5 \cdot 0\end{array}$ & $\begin{array}{l}6 \cdot 9 \\
1 \cdot 0\end{array}$ \\
\hline 8 & $13: 14$ & $\mathrm{I}$ & $1 \cdot 7$ & $5^{\circ} 0$ & $1 \cdot 9$ \\
\hline 9 & $12: 14$ & I & $I \cdot 7$ & $2 \cdot 5$ & $\cdots$ \\
\hline \multicolumn{2}{|c|}{ Total no. of cells examined } & 60 & ... & 40 & I 59 \\
\hline \multicolumn{2}{|c|}{ Mean no. of laggards per cell } & $5 \cdot 2$ & $\cdots$ & $4 \cdot 8$ & $4 \cdot 4$ \\
\hline
\end{tabular}

distribution was varied as well and only one-sixth of the P.M.C's. at $\mathrm{AI}$ had seven laggards. In over 80 per cent. of the cells one or more of the univalents were included intact with the bivalents when they passed to the poles. This random distribution will give dyad nuclei containing from 12 to 19 chromosomes plus a varying number of divided univalents.

At TI the chromosomes that are crowded at the poles cannot be counted but the lagging univalents are clear. The mean of 4.8 univalents (table 2) again shows that 7 univalents were not equationally divided at AI. Univalents were split in all cells but in Io per cent. of the cells both halves of one or more univalents were passing to the one pole.

In 4.3 per cent. of the P.M.C's. there was misdivision of the centromeres in one or more lagging univalents. 


\section{SECOND DIVISION}

Interphase.-Lagging univalents or daughter univalents excluded from the TI nuclei form micronuclei (table 3). The difference in plant B may be due to chance or it may also be a reflection of the better pairing in this plant than in $\mathrm{D}$. The sizes of the micronuclei vary considerably. Most frequently each one is an excluded daughter univalent.

Anaphase II and telophase II.--Sufficient cells could not be scored to give a comparison of the number of chromosomes at each pole at AII but at TII laggards are clear. The results given in table 2 refer to only half-tetrads. They were scored in this manner because of the lack of synchronisation in the two halves. While the results are again taken from plant $\mathrm{C}$, for a comparison with earlier stages, laggards were observed in all pentaploids and near-pentaploids.

There was ro per cent. misdivision at TII. This is probably an under-estimate because in some cells the centromeres were stretched by movement forces. Such cells were not scored as having misdivision but a break is more probable than inclusion of two separated arms.

In the earliest reports, a random distribution of the 7 chromatids at second division was assumed. Later, Kihara and Matsumura (1940) suggested that the univalents went in groups to the poles. There is no evidence in my material for such a grouping at AII or at TII.

Tetrads.-Most of the tetrads, like the dyads, had one or more micronuclei (table 3). Here I agree with Love (I94I). Microcytes were formed in less than one per cent. of the tetrads. It is evident from the large number of micronuclei both in pentaploids and nearpentaploids, that there is considerable chromosome loss.

TABLE 3

Frequency of micronuclei formed in dyads and tetrads from excluded laggards arising in pentaploid and near-pentaploid hybrids

\begin{tabular}{|c|c|c|c|c|c|c|c|c|}
\hline \multirow{2}{*}{$\begin{array}{l}\text { Plant and } \\
\text { chromosome } \\
\text { number }\end{array}$} & \multicolumn{4}{|c|}{ Dyads } & \multicolumn{4}{|c|}{ TEtrads } \\
\hline & $\begin{array}{l}\text { No. of } \\
\text { cells } \\
\text { examined }\end{array}$ & $\begin{array}{l}\text { Per cent. } \\
\text { with } \\
\text { micro- } \\
\text { nuclei }\end{array}$ & $\begin{array}{r}\text { Mic } \\
\text { pe } \\
\text { Range }\end{array}$ & $\begin{array}{l}\text { adei } \\
\text { ad } \\
\text { Mean }\end{array}$ & $\begin{array}{l}\text { No. of } \\
\text { cells } \\
\text { examined }\end{array}$ & $\begin{array}{l}\text { Per cent. } \\
\text { with } \\
\text { micro- } \\
\text { nuclei }\end{array}$ & $\begin{array}{r}\text { Micr } \\
\text { per } \\
\text { Range }\end{array}$ & $\begin{array}{l}\text { clei } \\
\text { ad } \\
\text { Mean }\end{array}$ \\
\hline \multirow{5}{*}{$\begin{array}{c}(2 n \stackrel{\mathrm{A}}{=} 35) \\
\mathrm{B} \\
(2 n=35) \\
\mathrm{C} \\
(2 n=35) \\
\mathrm{D} \\
(2 n=34) \\
\overline{\mathrm{E}} \\
(2 n=36)\end{array}$} & 277 & 93.5 & $1-9$ & $3 \cdot 5$ & $34^{8}$ & $99 \cdot 4$ & $1-9$ & $4 \cdot 0$ \\
\hline & 457 & $78 \cdot 3$ & I-5 & $I \cdot 6$ & 250 & $99^{\cdot 6}$ & I -9 & 3.7 \\
\hline & $\cdots$ & $\ldots$ & & & $35^{6}$ & $98 \cdot 6$ & I -8 & $3 \cdot 0$ \\
\hline & 203 & $96 \cdot 6$ & I-7 & $3 \cdot 7$ & $5^{24}$ & $98 \cdot 7$ & I-IO & $4 \cdot 4$ \\
\hline & 229 & $90 \cdot 0$ & I -6 & $2 \cdot 4$ & 279 & $96 \cdot I$ & I-6 & $2 \cdot 3$ \\
\hline
\end{tabular}




\section{POLLEN GRAINS}

The micronuclei formed in the tetrads persist in the pollen grains until the cytoplasm becomes vacuolated and lines the wall. Then they are absorbed, presumably by the cytoplasm. At first mitosis less than 5 per cent. of the P.G's. had micronuclei ; these were mostly inactive.

At the time of first mitosis, while there was some variation in P.G. size there was no correlation between size and number of chromosomes in the P.G's., e.g. those grains with 14 were similar in size to those with 21. Approximately I per cent. of micro-pollen grains were formed from microcytes. After Ist mitosis the grains become filled with starch and the cytoplasm becomes more dense. Differential growth rates due to unbalanced P.G's. could thus arise after Ist mitosis.

P.G's. with numbers from I4-2I were present in anthers which varied in age (as tested by the number of bi-nucleate and uni-nucleate grains present, table 4). This might mean that there is no differentiation with respect to entry into the first mitosis. However the number

TABLE 4

Distribution of the P.G's. with varying numbers undergoing mitosis, from anthers at different ages

\begin{tabular}{|c|c|c|c|c|}
\hline $\begin{array}{c}\text { Binucleate P.G's. } \\
\text { in the anthers }\end{array}$ & $\begin{array}{c}\text { Approx. no. } \\
\text { of P.G's. in } \\
\text { the squash }\end{array}$ & $\begin{array}{c}\text { No. of P.G's. } \\
\text { at metaphase }\end{array}$ & $\begin{array}{c}\text { Range in } \\
\text { chr. nos. } \\
\text { of P.G's. }\end{array}$ & $\begin{array}{c}\text { Mean } \\
\text { chr. no. }\end{array}$ \\
\hline 37 per cent. & 1000 & 19 & $15-20$ & $17 \cdot 4$ \\
$40, "$ & 1000 & 19 & $14-21$ & $17 \cdot 1$ \\
70, & 1000 & 31 & $15-20$ & $17 \cdot 4$ \\
\hline
\end{tabular}

of P.G's. actually undergoing division was usually less than 2 per cent. of the cells. Therefore the results may not be indicative of the true picture.

At first mitosis, there is no significant difference between the three pentaploids for the various classes from 14 to 21 (table 5). Even in plant $\mathrm{D}$, which has a maximum of 13 pairs at $\mathrm{MI}$, the distribution of the P.G's. does not deviate very much from the others.

The theoretical frequency (fig. I) is based on the chance distribution of 7 univalents. The chief differences between the observed and theoretical are the depression of intermediate numbers and an excess of both 14 and 2I P.G's. There are several factors which have altered the proportion of the classes.

(i) Loss of univalents as micronuclei (table 3 ) reduces the chance that all 7 univalents will go to one pole. This should cause a reduction in the higher numbers. 
(ii) Reduced pairing (table I) gives more than 7 univalents. This should extend the range in chromosome numbers.

(iii) Random distribution of non-divided univalents at AI (table 2). This should cause an excess of intermediate numbers.

(iv) Competitive ability of balanced P.G's. This will bring about an equilibrium with the first three factors-more P.G's. with higher numbers ; fewer with a complement of less than 14 or more than 21 ; and fewer P.G's, with intermediate numbers.

\section{TABLE 5}

Distribution of the chromosome numbers at 1 st and and mitosis in the P.G's. of $5 \times$ and near-5x plants

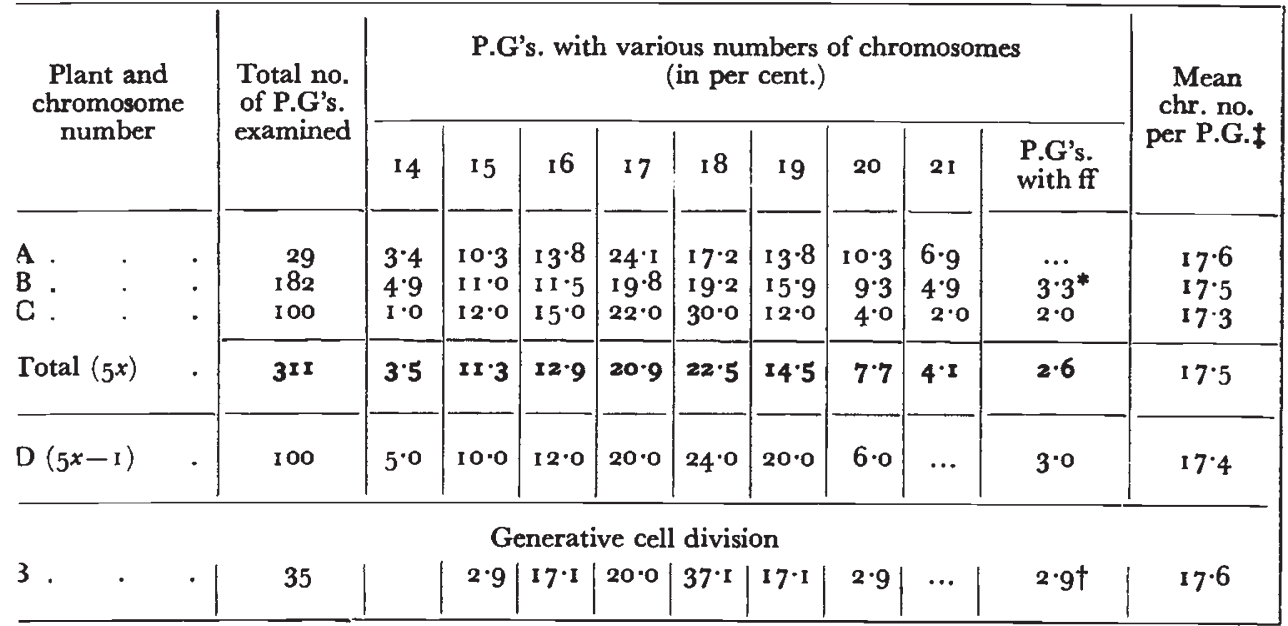

* Including two abnormal P.G's. one with 10 and one with 12 chromosomes.

$\dagger$ One abnormal P.G. with 32 chromosomes.

† Omitting fragments.

$$
\mathrm{ff}=\text { fragments. }
$$

An examination at the second division should show whether unbalanced P.G's. with intermediate numbers suffer more in competition as they mature and become filled with starch. Unfortunately the division of the generative cell is difficult to study and the few counts (table 5) were made up from several slides. Therefore while it does mean that many intermediate-numbered P.G's. do form gametes, it does not show the proportions of each type that are undergoing division at any one time.

Mature pollen prior to anthesis showed: (i) size differences, (ii) aborted grains, approximately ro per cent., (iii) some P.G's. in which division had failed, (iv) differences in the amount of starch in the grains. The aborted grains and those with reduced starch were probably due to unbalanced combinations.

My count of the chromosome number in P.G's. agrees closely with those of Thompson and Armstrong (1932) and Matsumura 
$(1936 a)$. These workers did not record fragments. With the new technique fragments are shown clearly (fig. $3 E$ ). The fragments in the P.G's. arise from misdivision of univalents. Five of the nine fragments were telocentrics. In the other four the positions of the centromeres were doubtful. There is a smaller proportion of P.G's. with fragments than was observed in the monosomic wheats (Morrison, I $953 a$ ). This reduction agrees with the reduced misdivision frequency at telophase.

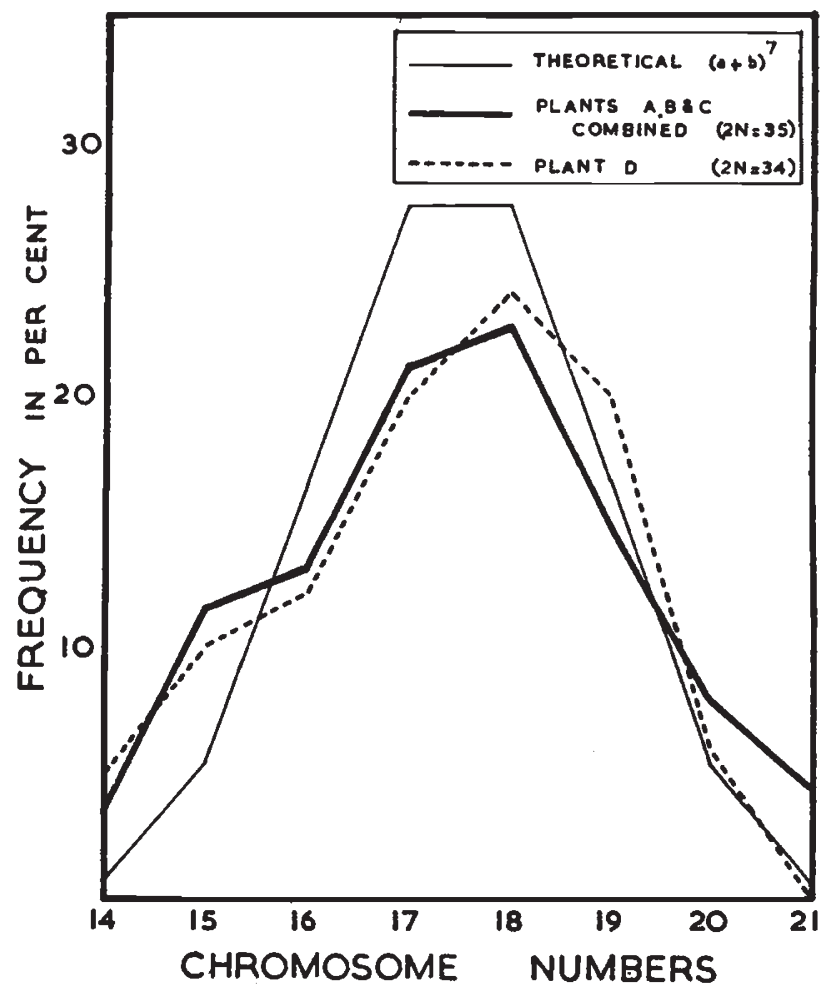

Fig. 1.-Frequency distribution of chromosome numbers in pollen grains in pentaploid and near-pentaploid plants.

The two hypoploid P.G's. (table 5) could result from either segregation after reduced pairing or from aneuploid cells. Besides the one delayed P.G. with 32 chromosomes there was one other in which a hyperploid number was present but the exact number could not be counted. These two P.G's. could arise either from hyperploid cells that originated prior to MI, or from restitution at AII.

\section{FERTILITY AND PROGENY}

The seed fertility of the pentaploids when selfed varied from zero in one plant to 37.5 per cent. in another. These figures agree with those generally quoted for pentaploid fertility (Thompson, I934, 
and Granhall, I 943). No differences were shown by the near-pentaploids; nor were there differences between bagged heads and those left uncovered.

The seeds from the pentaploid were germinated on filter paper. The somatic complement was determined when the plants were only a few days old (fig. 2). In this manner abnormalities that might be eliminated from the somatic line could be observed. There were

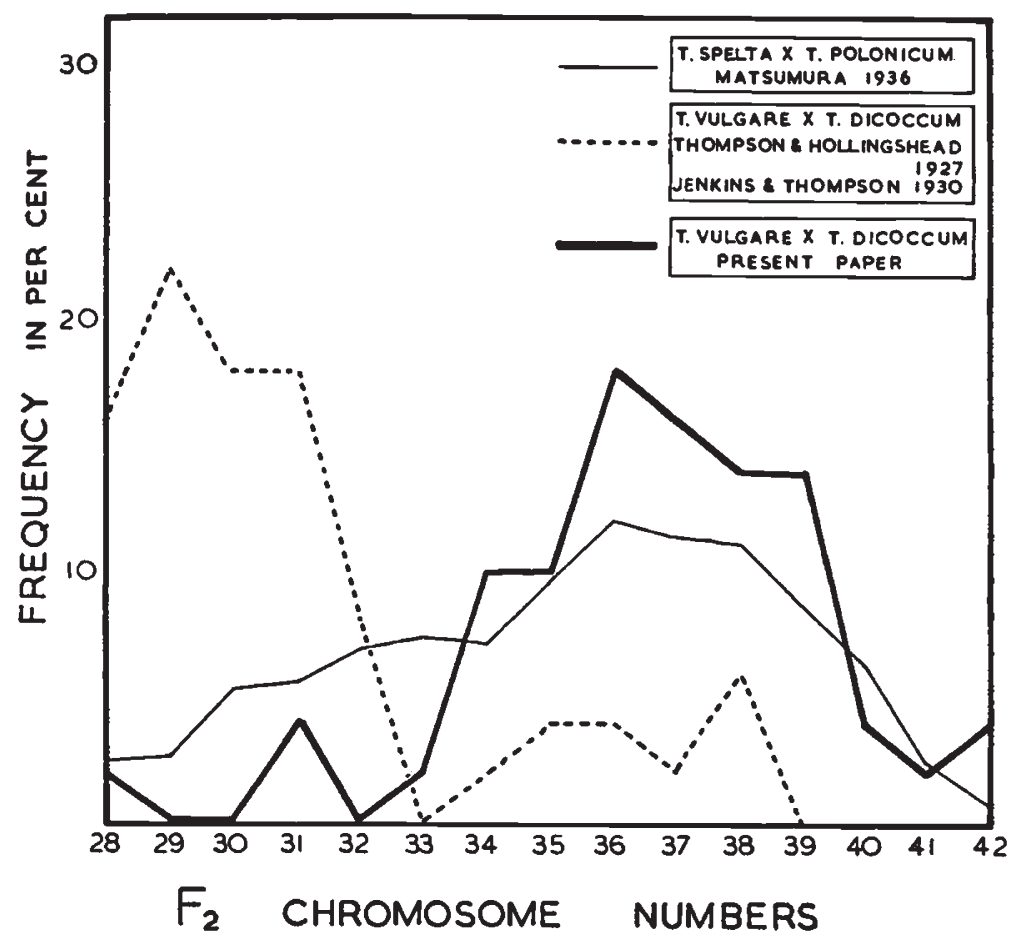

FIG. 2.-Frequency of chromosome numbers in pentaploid $F_{2}$ populations. A comparison of results for different species crosses and different localities.

I6 seeds $(24 \cdot 2$ per cent.) which did not germinate. No doubt they had unbalanced combinations in zygotes or endosperms.

In one of the root-tips with 37 chromosomes there was a dicentric chromosome and in one with 40 there was a chromosome deficient for part of an arm. No inversion bridges or trivalents were observed at meiosis so it is unlikely that the dicentric arose in this manner. Breakage (misdivision of centromeres) occurs at both TI and TII. The dicentric may have arisen from some anomalous breakage and reunion at these stages or in the resting nucleus. The short deficient chromosome could have arisen from similar breakage.

Kihara and Matsumura (1940) have advanced several reasons for the skew distribution in the $\mathrm{F}_{2}$ of $T$. polonicum $\times T$. spelta. Some of these factors: (i) competition in pollen tube growth, (ii) selective fertilisation, (iii) elimination of unbalanced gametes, either through 
zygotic or endospermic media were also suggested by Thompson (1934). To explain the difference between the polonicum-spelta and the vulgare-dicoccum pentaploids of Thompson and co-workers (fig. 2) the Japanese workers supposed that more univalents were lost. Counts of chromosome numbers in P.G's. do not uphold this supposition.

Chromosome counts made on mature $\mathrm{F}_{2}$ plants would not include any of those plants which could germinate but not survive until microsporogenesis because of their unfavourable genotype. Some of the difference between the work done in Canada on T. dicoccum $\times$ $T$. vulgare and my results can therefore be explained. Some of the difference may be due to chance selection and some may be an influence of environment. Certainly the dissimilarity between expected results and those observed shows that a strong selective elimination is operating and its effect has been variable in the three cited experiments.

\section{SUMMARY}

I. The 35 chromosomes in pentaploid wheat crosses often form less than 14 bivalents. In the 34 chromosome plants only 13 bivalents were formed and in the 36 chromosome plants trivalents occur in 60 per cent. of the cells.

2. Univalents behave similarly in pentaploid and near-pentaploid plants. At AI the univalents do not all divide : some go undivided to the poles.

3. One or more micronuclei are formed from excluded chromosomes in about go per cent. of the dyads and in nearly all the tetrads.

4. Centromeres of univalents misdivide at TI and TII in some cells to give telocentrics which are included in the pollen grains.

5. Pollen grains with chromosome numbers from 14 to 21 are formed in proportions departing slightly from the chance distribution of univalents.

6. $\mathrm{F}_{2}$ progeny showed 28 to 42 chromosomes. The distribution shows strong selective elimination which differs from that in other experiments.

Acknowledgments.-I gratefully acknowledge the assistance of Dr C. D. Darlington under whose guidance the work was completed and the manuscript prepared and financial assistance from the National Research Council of Canada.

\section{REFERENCES}

AASE, H. C. 1935. Cytology of cereals. Bot. Rev., I, 467-496.

GRANHALl, I. I 943 . Genetical and physiological studies in interspecific wheat crosses. Hereditas, 29, 269-380.

horton, E. s. 1936. Studies in the cytology of wheat and of a wheat species hybrid. Amer. F. Bot., 23, I21-1 29.

jenkins, J. A., AND thompson, w. P. 1930. Chromosome conditions in the second and third generations of pentaploid wheat hybrids. Canad. 7. Res., 2, 162-1 70. KIHARA, H. I938. Cytogenetics of species hybrids. Curr. Sci. Special number "Genetics", pp. 2 1-23. 
KIHARA, H., AND MATSUMURA, s. 1940. Weitere Untersuchungen über die pentaploiden Triticum-Bastarde. XII. Schlussmitteilung. Fap. F. Bot., 11, 27-39. LI, H. W., PaO, W. K., AND LI, c. H. 1945. Desynapsis in the common wheat. Amer. F. Bot., 32, 91-101.

LOVE, R. M. 1941. Chromosome behaviour in $F_{1}$ wheat hybrids. I. Pentaploids. Canad. F. Res., 19, 351-369.

MATHER, K. 1935. Chromosome behaviour in a triploid wheat hybrid. $Z$. Zellforsch., 23, 11 7-1 38 .

Matsumura, s. 1936. Weitere Untersuchungen über die pentaploiden TriticumBastarde. V. Beziehungen zwischen Chromosomenzahlen und Sterilität sowie einigen morphologischen Eigenschaften in der $\mathrm{F}_{2}$-Generation des Bastardes T. polonicum $\times$ T. spelta. Fap. F. Bot., 8, 65-83.

MATSUmURA, s. 1936a. Weitere Untersuchungen über die pentaploiden Triticum -Bastarde. VI. Häufigkeit der verschienden-chromosomigen Pollenkörner bei dem Bastard T. polonicum $\times$ T. spelta. Fap. F. Bot., 8, 189-204.

MORRISON, J. W. 1953. A new technique for pollen grain study in the Gramineae Canad. 7. Agr. Sci., 33, 399-341.

MORRISON, J. w. 1935a. Chromosome behaviour in wheat monosomics. Heredity, 7, 203-217.

THompson, w. P. 1934. The causes of the cytological results obtained in species crosses in wheat. Canad. F. Res., 10, 190-198.

THOMPSON, W. P., AND ARMSTRONG, J. M. 1932. Studies on the failure of hybrid germ cells to function in wheat species crosses. Canad. F. Res., 6, 362-373.

THOMPSON, W. P., AND hollingshead, L. 1927. Preponderance of dicoccum-like characters and chromosome numbers in hybrids between Triticum dicoccum and Triticum vulgare. F. Genet., 17, 283-307. 
FIG. 3.-Photomicrographs from pentaploids. A to F I I20x, G at I680 magnification.
A. $\mathrm{MI}, 14^{11} 7^{1}$.
B. MI, reduced pairing, $I^{11} 13^{1}$.
C. AI, abnormal separation $18: 17$, no laggards.
D. P.G. mitosis, 18 chromosomes.
E. P.G. mitosis, I6 chromosomes plus telocentric at nine o'clock.
F. 2nd P.G. mitosis, 17 chromosomes.
G. Root-tip mitosis of $\mathbf{F}_{2}$ seedling, 38 chromosomes. 

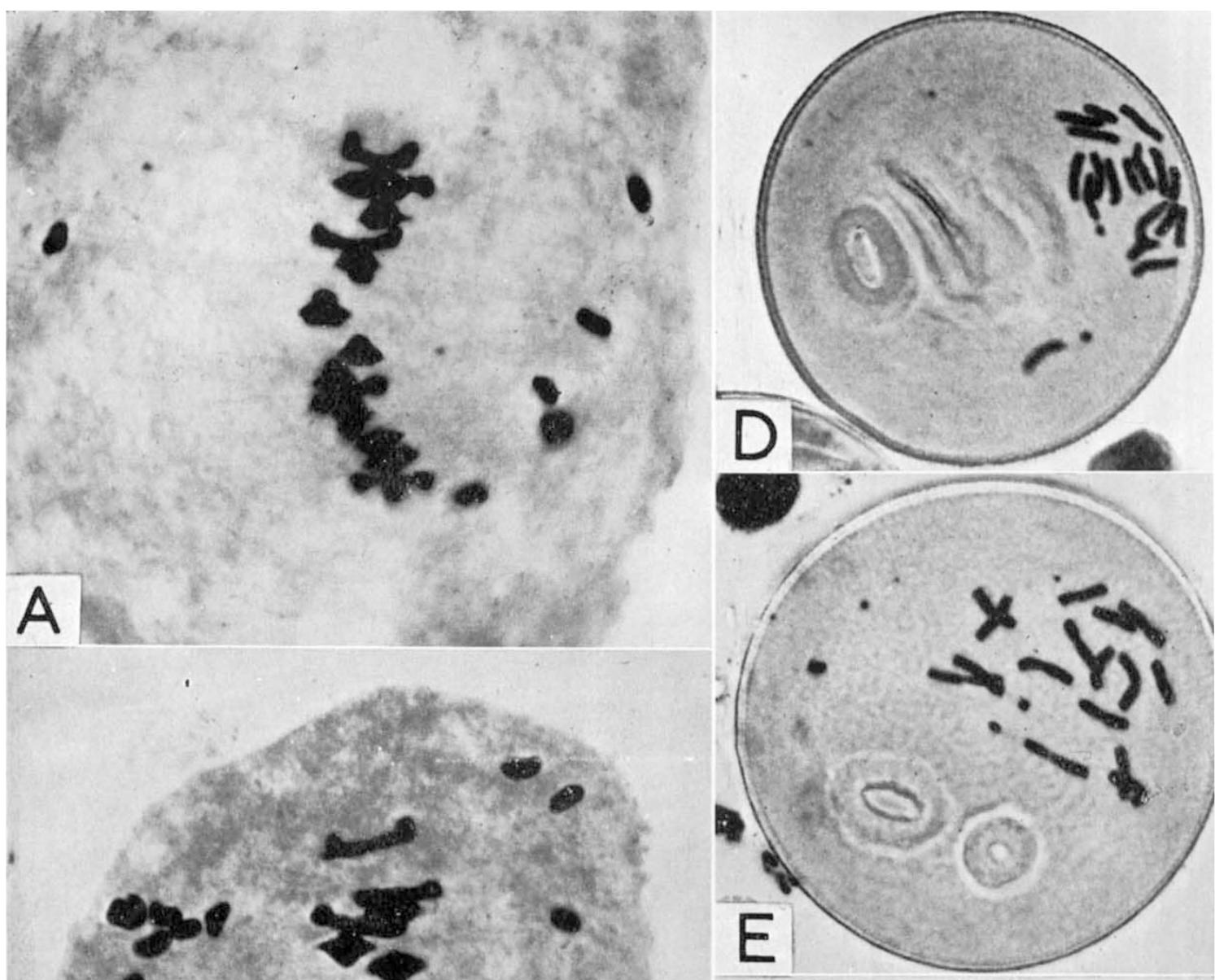

A
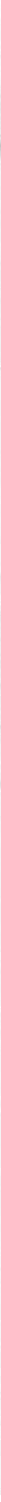